\title{
Stakeholder Governance Network in Tourist Destination: Case of the Komodo National Park and Labuan Bajo City, Indonesia
} Ambar Widaningrum $^{\mathrm{a}}$ and Janianton Damanik ${ }^{\mathrm{b}}$

${ }^{a}$ Department of Public Policy and Management, Faculty of Social and Political Sciences, Universitas Gadjah Mada, ${ }^{\mathrm{b}}$ Indonesia and Tourism Studies Center, Universitas Gadjah Mada aambarwid@ugm.ac.id, bantondmk@ugm.ac.id

\begin{abstract}
This study has attempted to find a pattern of stakeholder governance network of tourism destinations. Since tourism is a sector which is relatively fragmented, tourism management requires coordination among stakeholders, governments of various levels, private sectors and communities. Stakeholder partnerships and inter-organizational collaboration are recognized as distinct relational forms through which organizations seek to achieve mutually beneficial outcomes that cannot be accomplished independently. Therefore study on stakeholder governance network is quite important, because it is directed to create an effective destination governance. It was found that the rapid changing of the tourism phenomenon both locally, nationally and globally required a quick response as well. They were not prompt to adapt to rapid changes, resulting in the management of destinations that carried out were not integrated. Activities were less coordination and synergy among stakeholders. Thus, management of stakeholders has to be synergistic, through a clear framework and has the same language, by creating a sort of cooperation or regulatory guidelines. This guidelines consist of a consensus on the unity of the platform that is the welfare of society and the social and economic benefits.
\end{abstract}

Keywords: Stakeholders' engagement; Inter-organizational co-operation in Indonesia; Tourism governance

\section{Introduction}

Komodo National Park and Labuan Bajo in West Manggarai regency, East Nusa Tenggara Province, which became one of the 10 major tourist destinations priorities set by the Indonesian government. "The gate point of world ecotourism in East Nusa Tenggara" is the tourism vision of Komodo National Park - Labuan Bajo and surroundings. The target of foreign tourists is around 500,000 tourists by 2019. Currently, Komodo National Park and Labuan Bajo and have been visited by about 91,000 foreign tourists per year with an average length of stay of 3-5 days and spent US $\$ 120$ to 200 per day or a total tourism revenue reached US \$40 million per year (Manggarai Barat Tourism Office, 2016). Tourist attractions in the area include cultural tours to nature. Travelers can see dragons on Komodo National Park, dive, and enjoy the natural scenery and cultural richness.

When the communication and transportation technologies developing rapidly, the tourism industry also increased. Labuan Bajo, West Manggarai regency capital is a city stopover heading Komodo National Park, which consists of several islands, such as Komodo Island, Padar and some beautiful beaches like Pink Beach in Komodo National Park. As a city transit, Labuan Bajo has a 
strategic position, since visited many overseas travelers. Unfortunately, the local government of West Manggarai has not prepared best possible transit destinations governance, although some supporting infrastructure has been facilitated by the central government, such as Komodo International Airport and sea ports. Although the tourism activities in Labuan Bajo and Komodo National Park has boosted the local economy, unfortunately the growth is not balanced with economic equality in the real sector. Development of the tourism industry is not in balance with the welfare of society. The poverty rate in West Manggarai regency, where the destination Komodo National Park and Labuan Bajo are still around 17.2 percent (Statistics Indonesia, West Manggarai Regency, 2016). This means that the economic growth of West Manggarai regency as the positive impact of the tourism industry, has not been evenly distributed. The growth of the tourism industry in this area will be exclusively economic growth, if the destinations governance is not done properly. Nowadays, it is recognizing that stakeholders such as residents, tourists and tourism business are important parts of a destination and have great influences on local social and economic development.

Many tourist destinations are now experiencing problems with communication among tourism stakeholders, so that their plans and activities become less synergistic. Planning and management of tourism development is more concentrated in the hands of a few institutions. Therefore it is difficult to mobilize resources that are actually enough to stimulate the development of tourism. The problem are further compounded by weak coordination and misinterpretation of authority possessed by stakeholders (de Araujo, and Bramwell, 1999; Roberts and F. Simpson, 1999). Several studies on the tourism governance in Indonesia also generate same conclusion, that weak governance is the main obstacle of Indonesian tourism development (Teguh and Damanik, 2012; Teguh, 2015). The nature of local government regulation is very partial and not yet accommodate the integrated and comprehensive destination management system. In addition, realization of the mechanism of rights and obligations of the tourism stakeholder, such as stakeholder participation, financing, monitoring, conflict resolution mechanisms, are not arranged in the frame of partnership (Damanik and Teguh, 2012). From organizational perspectives, the institutional arrangement is characterized by unclear division of authority and responsibility on tourism related issues. Stakeholder's engagement is also very low, because of limited interorganizational relations and inter-organizational coordination and narrow understanding on tourism administration and the role of local government tourism organization (Widaningrum \& Damanik, 2016). The strength of collaboration in the context of tourism development governance is believed to strengthen the establishment of conducive communication, cooperation and coordination in the destination area.

This study attempts to find a stakeholder governance framework of tourism destinations. This study is quite important, because it is directed to create an effective destination governance. A well-managed tourist destination will bring benefits, either directly or indirectly, will stimulate and encourage the entry of tourists, investors and businesses. In turn, new employment opportunities increase, the local revenue increases, economic growth rises, so that the living standards of the general population in the area will also be increased. 


\section{Literature review}

Tourism is characterized as public sector that is integrated with other public sectors in economic development. Tourism cannot be separated from economic power to change the world in the future (Dwyer, et al, 2009). Tourism is an open industry and its related aspects such as complex political, social, and environmental and technology, are requiring an appropriate response. As the sector is relatively fragmented, tourism management requires coordination among stakeholders, governments of various levels, private sectors and communities, to develop cooperation complementary to one another (OECD, 2012). A tourism destination has two primary roles and a number of important supporting roles. First and foremost, it must seek to enhance the social and economic well-being of the residents who live within its boundaries. Secondly, to be classified as a tourism destination, it must provide this enhancement of resident wellbeing by offering a range of activities and experiences of the kind that we identify as "tourism" experiences (Bornhorst, Ritchie, Sheehan, 2010).

Baggio, et.al (2010) stated that there is a strong acknowledgment that tourism is a network of collaborating stakeholders. The basic premise of tourism destination management is that through cooperative planning and organizational activities, the effectiveness of these joint interactions can be improved to the benefit of stakeholders. Destinations are both the sum of their component parts and more than a collection of parts; destinations rather than individual service providers are what modern consumers perceive as the units of tourist choice. This description indicates some issues and complications in destination governance which includes: stakeholders, the dynamic of interaction between stakeholders and linkages between agencies. Interaction and complex network of stakeholders must strengthen destination governance.

Since tourism destination governance is an emerging research subject, very little tourism research has so far focused on the effectiveness of tourism governance (Zhang \& Zhu, 2014). The strengths and weaknesses of certain governance networks and their relative effectiveness have not been explicitly examined to date (Beaumont $\&$ Dredge, 2009). The main element in the governance of tourism industry is the ability to identify key factors that are diverse and in dynamic changes, and how these factors interact (Dwyer, et.al. 2009). This governance covers some aspects: the nature of tourism sectors, the complexity of the relationships between the organizations and the collaboration in the decision making process between stakeholders to consider several factors of policy implementation using both approaches: top to bottom (top-down) or bottom to top (bottomup) (Wang and John Ap, 2013).

The importance of destination stakeholders

Freeman (1984) defines a stakeholder as "any group or individual who can affect, or is affected by, the achievement of a corporation's purpose'. Gray (1989) defines a stakeholder as a person who has the right and capacity to participate in the process; thus, anyone who is impacted upon by the action of others has a right to be involved. Bryson's definition of stakeholder (2004) is people or small groups with the power to respond to, negotiate with, and change the strategic 
future of the organization". Based on some of these definitions, stakeholders can be understood simply as a party that can be affected and or influence a decision. In the context of tourism policy, stakeholders are those affected or affect a tourism policy.

The dynamics of a destination system is its complexity. However, the definition of complexity is an unresolved issue and many different proposals have been made for its characterization and measurement (Baggio, et al., 2010). Moreover, Sheehan \& Rictchie (2015) stated that while not directly applying stakeholder theory in tourism, a few authors have taken a perspective based on collaboration and inter organizational relations. Destination Management Organizations (DMO) potentially have a great diversity of stakeholders. Medeiros de Araujo and Bramwell (1999) makes an additional argument for collaboration. It engages all interested parties in the decision making process by allowing them to take responsibility, enhance their self-reliance, and their own awareness of the issues - all of which enables them to enjoy a greater degree of consensus and shared ownership. As stated by Roberts and Simpson (1999), the fragmented nature of the tourism industry creates a recognized need for coordination and collaboration in planning. Dwyer et al. (2009) mentioned that achieving competitive advantage in times of rapid change requires stakeholders to have a clear understanding of the direction of change and its implication for business or destination management. Baumer and Horn (2013) categorize the role of stakeholders as follows: (1) Key stakeholders are those who are directly affected by a positive or negative impact of a policy; (2) Stakeholders are supporting those who become intermediaries in helping the process of realization of the policy / regulation (donors, implementing, monitoring, and others); and (3) Stakeholders are the core of their strong influence in relation to the problems and needs of a particular policy or regulation. Savage et.al (1991) divides the typology of stakeholders based on each player's potential to cooperate with the organization. They explain that the potential for cooperation is a function of a willingness to cooperate, which is primarily driven by the dependence of stakeholders on the organization. Stakeholders were assessed as having a high or low potential to threaten to organization and potential to cooperate with organization. One more important aspect as mentioned by Aas, Ladkin and Fletcher (2005) is communication. Establishing channels of communication is perceived to be a straightforward and initial step towards stakeholder involvement. However, in reality, there are many issues to consider before this can be achieved.

\section{Research method}

This study employed a descriptive research design and using case study method. The goal of this research design is to develop an in-depth understanding of the problems and issues pertaining to tourism destination and stakeholders. (Yin, 1994; Yin, 2003). Case study is an approach to research that facilitates exploration of a phenomenon within its context using a variety of data sources: a) a large variety of factors and relationships are included, b) no basic laws exist to determine which factors and relationships are important, and c) the factors and relationships can be directly observed (Yin, 1994; Baxter and Jack, 2008). Since stakeholder governance network in tourism destination in Indonesia has not been understood very well, an understanding of the 
nature of the problem affecting tourism destination policy and stakeholders network are necessary to support tourism destination policy.

This research was conducted in the Komodo National Park (KNP) and Labuan Bajo City. KNP is part of West Manggarai administration area, and Labuan Bajo is the capital of West Manggarai regency. The management of KNP is structurally managed by the Ministry of Forestry (Ministry of Forestry, UNESCO and CIFOR, 2003). The chosen areas are based on some identified characteristics: a) social and cultural characteristics and unique physical environment; b) adequate infrastructure to support the development of destination; c) diversity of attraction; d) potential to attract tourists: and e) embryonic social institutions and economic activities related to tourism; f) a strategic area of tourism and officially declared as the Destination Marketing Organization (DMO) by the Ministry of Tourism and Creative Economy of Indonesia and ; g) one of the tenth Special Economic Zones in Tourism (Kawasan Ekonomi Khusus bidang Pariwisata) as declared by the Government of Indonesia in 2016.

Two categories of data were gathered: primary and secondary data. Primary data were collected through survey and interviews to obtain in-depth information. The respondents for survey and the informants for the interviewees were selected from various actors related to tourism activities at different administrative levels in order to gain insights from different perspectives. They are stakeholders from various institutions involved in tourism activities: governments (local and national level), hotels, culinary association, tour agents and tourism guides. The survey was focused on the understanding of tourism actors and stakeholders about the exercise of tourism policy implementation. Furthermore, in-depth interviews were conducted to complement the survey data. The interviews were focused on two main questions:

1) How does the local Tourism Office (TO) get tourism policy implemented? This question aims to clarify the context of tourism policy implementation. Some probing was asked depending on informants and interviewees' responses, such as: a) how does the local TO cooperate with other government organizations and stakeholders? b) How do stakeholders concern and put their interest in tourism policy formulation process and implementation?

2) What are the factors that limit or enable stakeholder tourism engagement? A set of open-ended questions was made which aims to identify any factors influencing the destination management and how destinations stakeholders work together to encourage a tourism success. Some probing was asked to the tourists who have visited some destination spots.

The secondary data were collected to supplement the primary data. The secondary data collected for this study came from a wide variety of sources, such as internal government documents, government publications, and some research reports about tourism of East Nusa Tenggara and its surroundings, in order to increase the reliability of the data.

\section{Findings and discussion}

In Indonesia, the tourism sector shows an interesting development in the last five years, in terms of potential resource of tourism and an increase of tourist visits (BPS, 2015). Tourism trends cannot be considered in isolation from key drivers that will shape Indonesian development. The 
Government of Indonesia is well aware of the significant role of tourism for development as well as the deficiencies in tourism governance. Strategic steps urgently needed. Based on Government Regulation Number 50 of 2011 on Indonesian Tourism Development Master Plan 2010-2015 states that the vision of national tourism development is the realization of Indonesia as a world class tourism destination countries, competitive, sustainable and able to encourage local development and welfare.

To realize the vision of national tourism development in Indonesia, particularly in Labuan Bajo and the Komodo National Park, some fundamental aspects of destination management should be monitored implementation, both from supporting and constraining aspects. Here is the finding from questionnaires distributed to the tourism stakeholders, a series of interviews and field observations.

\section{Tourism stakeholders}

Almost all tourist destinations have a great diversity of stakeholders. Using Baumer and Horn (2013) typology of stakeholder, below is list of stakeholders and its role associated with the development of tourism of Labuan Bajo and Komodo National Park.

1. Key stakeholders are those who are directly affected by a positive or negative impact of a policy: Bappeda (the local planning agency that serves as the district government authorities to establish development plans of all sectors, including tourism); Office of Komodo National Park (manager of the National Park conservation area) and Local Tourism Office (this office serves to set the agenda for tourism development in the region, especially developing a master plan for tourism, attractions and accommodation setting standards, improving the competence of human resources, marketing of tourism destinations with the target of special interest tourists. This office has to coordinate with the Bappeda).

2. Stakeholders are supporting those who become intermediaries in helping the process of realization of the policy (Office of Transportation, Travel Agency, Association of Tourist Guides, Hotels, Restaurants).

3. Stakeholders are the core of their influence in relation to the problems and needs of a particular policy (Office of Marine and Fisheries Agency; Office of Agriculture, Laboratory of the Marine and Food Agency, Office of Animal Husbandry, NonGovernment Organizations (NGOs), Farmers, Banks and cooperatives, Wholesalers / Distributors. Local Communities, Culinary Services Association.

Ideally, the eighteen stakeholders have potential for cooperation and interdependence with other stakeholders. They also require close cooperation and coordination between agencies, both vertically and horizontally. Some agencies can indeed be referred to as stakeholders directly related to tourism activities or stakeholders that are not directly related to tourism activities but they had a very important role. Nevertheless, cooperation and interdependence among stakeholders were not easily identified. Some interviews with stakeholders resulted in a need of cooperation 
which were identified by the duties and functions of each stakeholder. It needed to be realized by creating a sort of cooperation or regulatory guidelines. Although each party understands that they can actually coordinate effectively with other stakeholders, but because operational grounding for cooperation does not exist, they do not make it a priority in their activities. It has also been written by Bäckstrand (2006), about the importance of the guidelines or regulations to manage the cooperation among stakeholders. Therefore, guidelines or regulatory action is important as a working guideline for all tourism stakeholders Labuan Bajo-Komodo National Park.

Stakeholder's management based vertical-horizontal regulation means cooperation and governance stakeholders will be executed through a set of guidelines or regulations of local government to the national cross-sectored manner. This includes the issue of whether the regulation is made in a participatory, transparent, or rules-based. For example, a mechanism of the development of tourism attractions arranged by applying duties and responsibilities of the technical institutions at the national, provincial and district levels, and not just between the ministries with the local tourism offices, but also between the local tourism offices with other local government offices. Such management is very effective to direct the pragmatic and technical actions by any local offices to support the development of the Komodo National Park and surrounding areas, so that the management of tourist areas are effective.

Based on the research results of Centre for Tourism Studies, Gadjah Mada University (2015) governance based vertical-horizontal regulations are not yet formed. Since tourism destination Labuan Bajo-Komodo National Park in Indonesia tourism priority areas, tourism management becomes a relatively new business. Regulations covering inter-institutional relationships, both vertically and horizontally, are essential for the implementation of governance and managing of Komodo National Park's tourism resources, since This Park has a selective function as an economic unit operating in a conservation area. Tourism governance plays an important role given the increasingly complex phenomenon of tourism. The rapidly changing dynamics of tourism phenomenon both locally, nationally and globally requires a rapid response as well. Thus, stakeholder management must synergize, through a clear and shared language framework, by institutionalizing a consensus on a unified platform of community welfare and social and economic benefits.

\section{Destination management}

As state in the OECD working paper (2012), destinations are increasingly seen as a strategic focus for the management of tourism. Then, to deal with the challenges inherent in tourism policy, there is a need to create effective governance systems and processes to define strategies and implement them to improve competitiveness and ensure the sustainable development of tourism. Baggio, et.al. (2010) also mentioned that the basic premise of tourism destination management is that through cooperative planning and organizational activities, the effectiveness of these joint interactions can be improved to the benefit of stakeholders.

As described in Figure 1, 65 percent of stakeholders stated that the DMO be the best institution as a manager of a tourist destination. Management through public private partnership 
mechanism is the second preferred choice (35 percent). The government is considered less appropriate as a destination manager. The parties involved in the management of tourism destinations are: tourism attractions manager; event organizer; hotel \& accommodation manager; restaurant and culinary; transport entrepreneurs/businessmen; travel agent; mass media; local communities; travelers; and NGO. This findings are in accordance with the result of in-depth interviews from some tourism activists, especially the tour agents. One quote from the interview is as follows:

"DMOs can work independently and professionally. If the management of tourism is coordinated by the government, the process can be complicated. Government officials often bond to the rules. If the rules are clear, it will be OK. The problem is, the rules often change, so it is difficult to follow the best step" (I-02, owner tourist agency).

Figure 1.

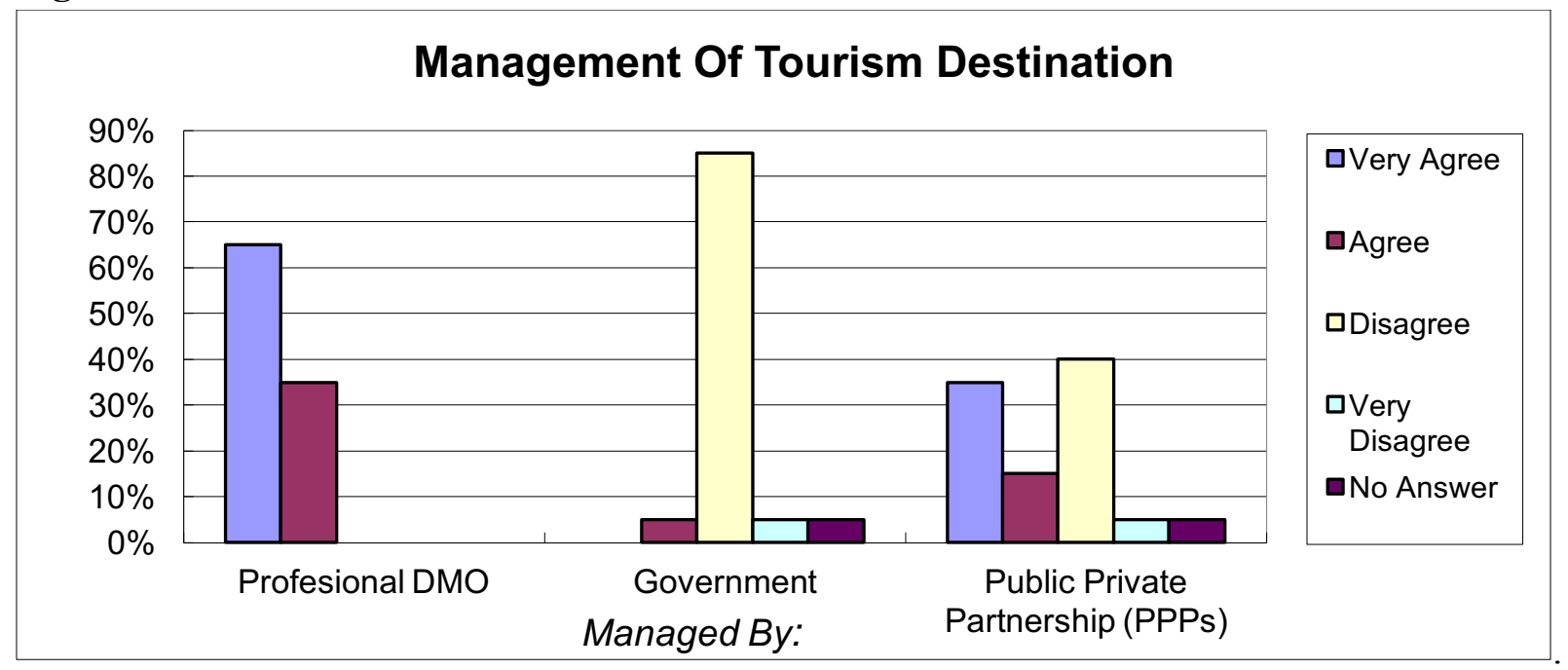

Figure 2 describes the role of each party in the destination management of destinations. It shows an unexpected result when event organizer has the smallest (45 percent) role in the destination management. They are seen as the other party from outside who participated in the success of tourism activities, although they also have an important part in the activities of a tourist attraction. This findings can be understood when respondents consider local communities can act as agents of tourism as well as the event organizer, in particular on the activities of cultural tourism attractions that are managed by the local communities. 
Figure 2.

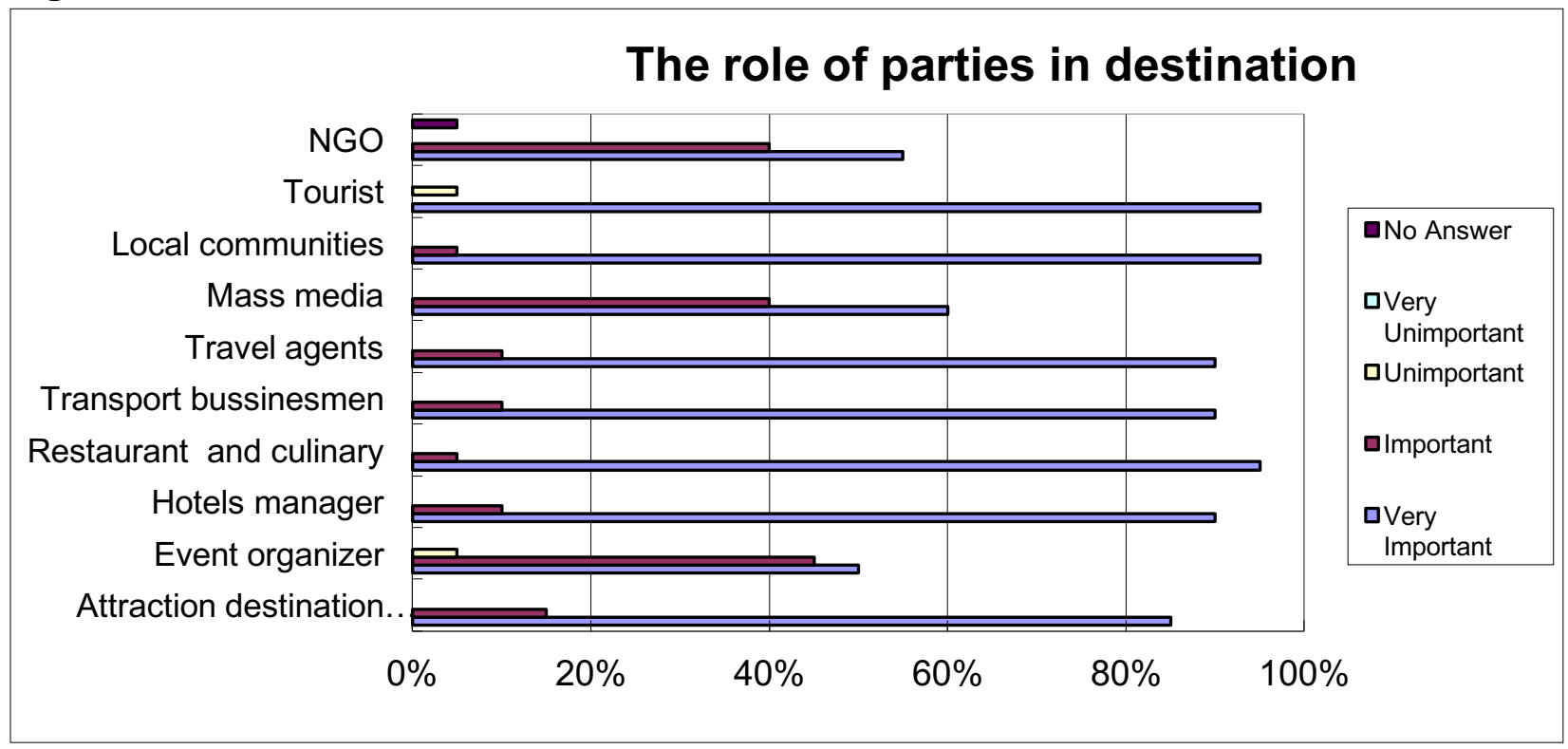

Destination Management effectiveness

The effectiveness of the tourism destinations management has always been a primary goal of all management activities. The activities indicated as effective if the objectives of the management can be achieved. Aspects that support the effectiveness of destination management are: leadership, cooperation and partnership, marketing and promotion, product development, community assistance and research \& planning. Figure 3 illustrates the response of the tourism stakeholders.

Marketing and promotion are the most effective factors. It is about 80 percent of respondents stated that marketing and promotion is the most effective aspects in facilitating of destination management objectives, and only 20 percent of respondents stated that cooperation and partnership is important facilitating aspect of the destination management. This evidence underlines result of primary data obtained through a series of stakeholders' interviews that cooperation and partnership among the stakeholders have not been recognized as an important aspect. Most of them also do not consider that cooperation and partnership are important facilitating factors of the success of a destination management. Previous study done by Widaningrum \& Damanik (2016) also mentioned that commitment among stakeholders are very varied. Different interest and vision do not easily negotiate. Sectored-egoism is also counted in. It is hampered the spirit of collaboration. 
Figure 3.

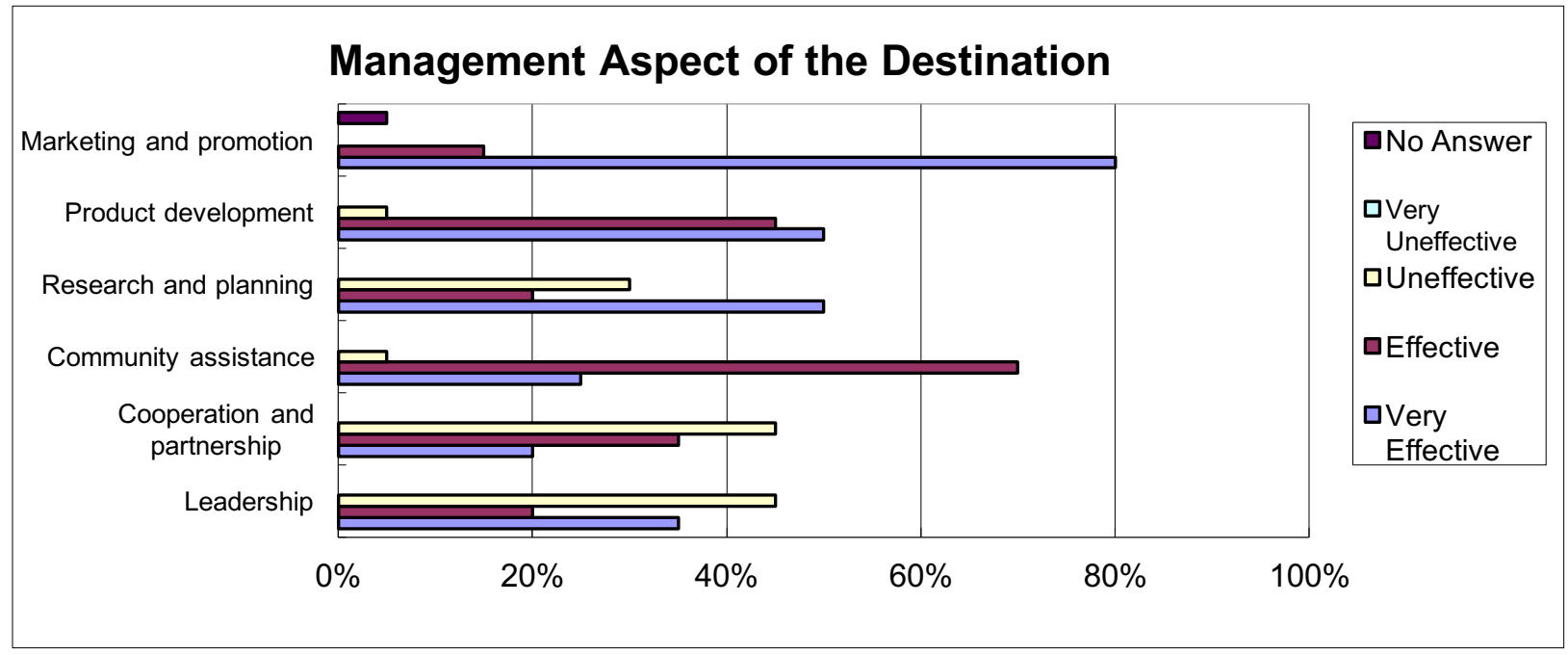

Figure 4 describes interaction activities did by stakeholders and the level of effectiveness of those interaction. In all aspects of interaction, most respondents explained that the effectiveness of the interaction is fine. The level of interaction effectiveness is a ranging from 55 percent to 65 percent. No variations in their answers. It is a curious findings that the interaction between the stakeholders is considered as an ordinary aspect, and not as an important aspect of governance destination.

\section{Figure 4}

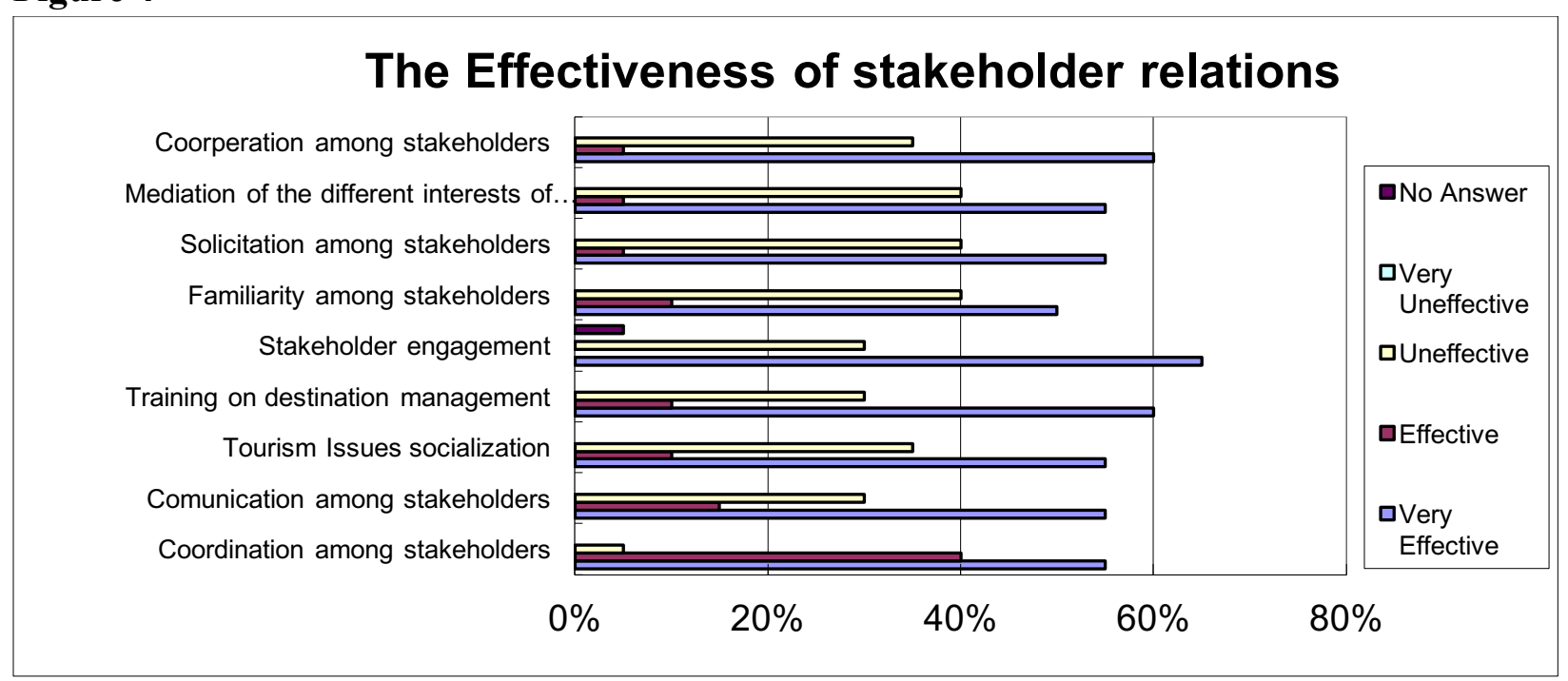

This data means that relationships between government and stakeholders or interest groups in the tourism field in are static. One interviewee from Tourism Administrative office described it, as follows:

"The Tourism Administrative Office should be able to lead this activity and Bappeda helps us to coordinate it. However, our office is actually an organization with limited authority 
for countless responsibility. We also have the task of coordinating with parties outside the government. We often have trouble doing this." (I-05, TO officer).

This phenomenon occurs if the division of roles, duties and functions of the organization is not clearly declared. Tourist visits that increase over time are not quickly responded by the stakeholders. Tourist Office is considered to be the principal institution that solves the problems in the destination, so the initiative to coordinate does not arise automatically.

\section{Conclusion}

In tourism activities, stakeholders were recognized as vital aspect, because they supply or facilitate funding, provide the tourism superstructure and product, participate in or support their programs, or influence governance. Result from survey raises a number of issues for discussion relevant to tourism development through stakeholder collaboration. Considering Indonesian vision of national tourism development: "the realization of Indonesia as a world class tourism destination countries, competitive, sustainable and able to encourage local development and welfare", it seems appropriate that authorities at a higher level and local level should initiate such action, by establishing communication with a clear direction for driving the issue forward. In a country where tourism faced planning and management challenges, collaboration might seem difficult to achieve, since there were some constraining factors influence the process of gaining result.

Ideally, tourism requires the presence of an institution that facilitates a comprehensive stakeholder cooperation, in which the functions for mutual interests formulated, synergized and executed consistently. The current system of governance in Indonesia has not yet fully encouraged regional innovation to undertake the development of tourism areas. From regulatory and policy aspects-both central and local-are still tinged with issues such as overlapping regulation and sectoral ego practices that hinder the emergence of cooperation. Therefore, the policy basis for developing institutional stakeholder cooperation was very weak, because there was no reference to action, and lack of coordination among stakeholders. Policy formulated in forums or meetings that were very technical and bureaucratic routines that generate multiple separated or partial programs. The meetings pattern was difficult to produce decisive actions, making it less synergistic effect on the cooperation of stakeholders. Appropriate pattern or format of institutional cooperation for these stakeholders should be designed so that they are easier to organize themselves, integrating the function, and bind themselves in a strong partnership. Thus, their response to the development of tourism can be more positive and constructive.

Another constraining aspect was about the variance of tourism stakeholder's backgrounds which were not clearly identified. Either government institutions, businesses, or local communities did not have references about who should be invited to be partners. They also did not understand how tourism development strategies should be prepared and implemented in a cooperation scheme.

From the results of the research and discussion above, the recommendations are as follows. First, since tourism governance is a complex network, it requires high commitment of stakeholders. Therefore, stakeholders must work together. Second, work in partnership needs a 
clear framework and a common goal, by creating some sort of cooperative or regulatory guideline. This guideline is to drive steps toward the ideal goal of developing a tourism project: community welfare and socioeconomic benefits.

\section{Acknowledgement}

This article is written based on the research titled "Application of governance model to improve destinations attractiveness in the Komodo National Park and Labuan Bajo, Phase 2", funded by the Universities' Research Program, the Ministry of Research, Technology and Higher Education, Republic of Indonesia, 2016.

The authors would like to thank Ms. Esti Cemporaningsih of the Tourism Studies Center, Universitas Gadjah Mada for her valuable assistance in conducting this research.

\section{References}

Aas, Christina, Adele Ladkin and John Fletcher. (2005). "Stakeholder Collaboration and Heritage Management”. Annals of Tourism Research, 32 (1): 28-48. doi:10.1016/j.annals.2004.04.005

Bäckstrand, K. (2006). "Multi-Stakeholder Partnerships for Sustainable Development: Rethinking Legitimacy, Accountability and Effectiveness", European Environment, 16: 290-306.

Beaumont, N. \& Dredge, D. (2009) "Local tourism governance: a comparison of three network approaches", Journal of sustainable tourism, 18 (1), 7-28.

Bornhorst, J.R.Tom, Brent Ritchie, Lorn Sheehan. (2010). "Determinants of tourism success for DMOs \& destinations: An empirical examination of stakeholders' perspectives”. Tourism Management 31: 572-589.

BPS-Statistics of Manggarai Barat Regency. (2016). Manggarai Barat 2016 in Figures. Manggarai Barat, East Nusa Tenggara, Indonesia.

Bryson, John M. (2004). "What to do stakeholders matter; stakeholder identification and analysis techniques", Public Management Review, 6(1): 17-36.

Centre for Tourism Studies. (2015). Aplikasi Model Tatakelola untuk Meningkatkan Daya Tarik Destinasi Pariwisata di Kawasan Taman Nasional Komodo dan Kota Labuan Bajo. (In Bahasa Indonesia). Yogyakarta: CTS, Universitas Gadjah Mada.

Freeman, R. (1984) Strategic Management: A Stakeholder Approach. Boston: Pitman.

Medeiros de Araujo, L., and B. Bramwell. (1999). "Stakeholder Assessment and Collaborative Tourism Planning: The Case of Brazil's Costa Dourada Project”. Journal of Sustainable Tourism 7:356-378.

Ministry of Forestry Republic of Indonesia, UNESCO dan CIFOR. (2003). Handbook 41, National Parks in Indonesia. Jakarta: Directorate General of Forest Protection and Nature Conservation.

OECD. (2012). OECD Tourism Trends and Policies. OECD Publishing.

Roberts, L., and F. Simpson. (1999). "Developing Partnership Approaches to Tourism in Central and Eastern Europe". Journal of Sustainable Tourism 7:314-330. 
Savage, G., T. Nix, C. Whitehead, and J. Blair. (1991). "Strategies for Assessing and Managing Organizational Stakeholders". Academy of Management Executive 5(2):51-75.

Sheehan, L. R., \& Ritchie, J. R. B. (2005). "Destination stakeholders: exploring identity and salience". Annals of Tourism Research, 32(3):711-734.

Teguh, F and Damanik, J. (2012). Ecotourism as a Strategic Bridge for the Use of Resources and Conservation of Flores Island, Indonesia, International Journal of Multidisciplinary Research, 1(9): 93-100.

Teguh, Frans. (2015). Tata Kelola Destinasi Membangun Ekosistem Pariwisata. Yogyakarta: Gadjah Mada University Press.

Gray, B. (1989). Collaboration Finding Common Ground for Multi-party Problems. San Francisco: Josey Bass.

Widaningrum, Ambar \& Janianton Damanik. (2016). "Improving Tourism Destination Governance: Case of Labuhan Bajo and The Komodo National Park, Indonesia". The Social Sciences, 11(21): 5043-51. DOI: 10.3923/sscience.2016.5043.5051

Zhang, H., \& Zhu, M. (2014). "Tourism destination governance: A review and research agenda", International journal of e-Education, e-Business, e-Management and e Learning, 4(2): 125-128. 